\title{
NOTES
}

\section{FEDERAL CRIMINAL ACTIONS AGAINST DISSOLVED CORPORATIONS}

$\mathrm{T}$ HE COMMON-LAW concept that a corporation ceases to exist upon its dissolution $^{1}$ under the laws of the state of incorporation ${ }^{2}$ has often en-

${ }^{I}$ A corporation might cease to exist for general purposes by a dissolution, United States v. P. F. Collier \& Son Corp., 208 F.2d 936 (7th Cir. 1953); United States v. Safeway Stores, Inc., 140 F.2d 834 (1oth Cir. 1944), or by a merger, United States v. United States Vanadium Corp., 230 F.2d 646 (roth Cir.), cert. denied, 351 U.S. 939 (1956), affirming in part United States v. Union Carbide and Carbon Corp., 132 F. Supp. 388 (D. Colo. 1955); United States v. Line Material Co., 202 F. 2d 929 (6th Cir. 1953), or by a consolidation, United States v. Cigarette Merchandisers Ass'n, Inc., 136 F. Supp. 214 (S.D.N.Y. 1955).

The terms "dissolve" and "dissolution" hereafter refer to all 3 forms of corporate termiuation: dissolution, merger, and consolidation.

2In Oklahoma Natural Gas Co. v. Oklahoma, 273 U.S. 257,259 (1927), Chief Justice Taft said, "Tt is well settled that at common law anc' in the federal jurisdiction a corporation which has been dissolved is as if it did not exist, and the result of the dissolution cannot be distinguished from the death of a natural person in its effect. [Citation of cases omitted.] It follows therefore that, as the death of the natural person abates all pending litigation to which such a person is a party, dissolution of a corporation at common law, abates all litigation in which the corporation is appearing either as plaintiff or defendant. ..."Accord, Defense Supplies Corp. v. Lawrence Warehouse Co., 336 U.S. 631 (1949); Chicago Title and Trust Co. v. Forty-One Thirty-Six Wilcox Bldg. Corp., 302 U.S. 120 (1937); National Bank v. Colby, 88 U.S. (2 I Wall.) 609 ( 1874 ); Mumma v. Potomac Co., 33 U.S. (8 Pet.) 281 (1834). This analogy was criticized in Marcus, Suability of Dissoloed Corporations-A Study in Interstate and Federal-State Relationships, 58 HARv. L. REv. 675, 677 (1945): "Dissolution of a corporation has often been referred to, in judicial discussions of this problem, as similar to the death of an individual. A number of statements of this sort are to be found in opinions of the Supreme Court, usually in cases where dissolution took place under statutes which were silent as to continuing the existence of dissolved corporations for purposes of suit. Such statements appear to represent only an uncritical search for analogies. Historically and practically, there are significant differences in the rules applicable to deceased individuals and to dissolved corporations." And the analogy has also been criticized on the basis that statutes allowing survival of civil actions beyond death have been construed not to apply to corporations. Comment, 21 U. CHr. L. REV. 480,482 (1954).

There must be some statutory authority for the prolongation of a corporation's existence, even for purposes of litigation. Defense Supplies Corp. v. Lawrence Warehouse Co., 336 U.S. 63 I (1949); Chicago Title and Trust Co. v. Forty-One Thirty-Six Wilcox Bldg. Corp., supra; Oklahoma Natural Gas Co. v. Oklahoma, 273 U.S. 257 (1927); United States v. P. F. Collier \& Son Corp., 208 F.2d 936 (7th Cir. 1953); United States v. Safeway Stores, Inc., 140 F.2d 834 (10th Cir. 1944). See Ballantine, CorporaTIONS $\$ \$ 315,316$ (1946 ed.); 16 FleTCher, PRIVATE CoRporations $\$ \$ 8142,8143$ (perm. rev. ed. repl. 1942, cum. supp. 1958). 
abled a corporation to avoid its legal obligations. This idea of corporate "death" has consequently evoked state "saving" statutes, under which a corporation is given an extended life, at least for the purpose of carrying on during the winding-up period those activities which are necessary to discharge its civil obligations. One significant question which raises in the application of these states enactments is whether they comprehend federal criminal actions against a corporation during the winding-up period. $^{3}$ To answer this question, federal courts have characteristically looked solely to the statute of the state of incorporation. All too frequently, a strict construction of saving statutes has impelled the conclusion that criminal actions did not survive dissolution.

Perhaps the most egregious instance of this unfortunate development is United States v. Safervay Stores, Inc., in which motions by six corporations to quash federal indictments for. violation of the Sherman Act ${ }^{5}$ were sustained on grounds that the corporations had been dissolved prior to the indictments. ${ }^{6}$ The decision rested upon a narrow interpretation of the words "suit," "action," "8 and "proceeding," which words

'See generally Marcus, supra note 2 ; Comment, 2 I U. CHI. L. REv. 480 (I954).

1140 F.2d 834 (Ioth Cir. 1944).

826 STAT. 209 (1890), I5 U.S.C. $\$ \S 1,2$ (1946).

- Other decisions dimissing federal prosecutions because of corporate dissolution are: United States v. Leche, 44 F. Supp. 765 (E.D. La. 1942), in which the corporation had dissolved under the Texas statute after indictment for violation of the Connolly Hot Oil Act; United States v. Line Material Co., 202 F.2d 929 (6th Cir. 1953), in which a Delaware corporation merged with another corporation after indictment for violation of the Sherman Act; United States v. United States Vanadium Corp., 230 F.2d 646 (10th Cir.), cert. denied, 351 U.S. 939 (1956), in which corporations incorporated in West Virginia and Delaware merged after indictment for violation of the Sherman Act. The court in the Vanadium decision refused dismissal of an indictment against a New York corporation which had merged with the other two, thus reversing in part United States v. Union Carbide and Carbon Corp., 132 F. Supp. 388 (D. Colo. 1955).

"The court construed the term "suit" in the statutes of Delaware, DEL. REv. CODE § 2074 (1935), as amended, 43 Laws of Del. 1941, ch. 132, § II, now DEL. CODE ANN. tit. $8, \S 278$ (1953) (slightly changed in form only), and of Nevada, NEv. CoMp. LAWS $\$ \S$ I 664, I666 (1929) (amended by NEV. REv. STAT. $\$ \S ~ 78.585,78.595$ (1957)), as not including a criminal prosecution. It has also been held in United States v. Union Carbide and Carbon Corp., supra note 6, affirmed in part, United States v. United States Vanadium Corp., supra note 6, that "suit" in the West Virginia statute, W. VA. CODE ANN. $\$ 3095$ (1955), did not include a criminal prosecution. In United States v. Line Material Co., 202 F.2d 929 (6th Cir, 1953), the court held "suit" to be the dominating word in the Delaware statute and that it did not mean criminal proceeding. But see United States v. P. F. Collier \& Son Corp., 208 F.2d 936 (7th Cir. 1953), in which the court held the word "suit" not to be dominant.

"The word "action" in the California statute, CaL. CIv. Code $\$ 399$ (I94I), now CAI. CORP. LAW $\$ \S 5400,5401$ (slightly changed in form only), was interpreted as not 
the various statutes employed to describe the activities surviving dissolution. ${ }^{10}$ The Saferway case has been strongly criticized as an invitation to violate the law, in that a corporation, for example, might profitably act in restraint of competition and then either dissolve or merge with another corporation in order to gain immunity from criminal responsibility. ${ }^{11}$ Such actions would, in effect, precipitate indirect state inter-

meaning criminal prosecution. Contra, United States v. Cigarette Merchandising Ass'n, ×36 F. Supp. $2 \times 4$ (S.D.N.Y. 1955), in which "action" was shown to include a criminal proceeding in New York.

"The term "judicial proceedings" in the Texas statute, TEx. Rev, Civ. STAT. ANN. art. 1388 ( 1945 ), was construed not to include criminal proceedings. Contra, Alamo Fence Co. of Houston v. United States, 240 F.2d I79 (5th Cir. 1957), as to "judicial proceedings." And see United States v. Maryland \& Virginia Milk Producers, Inc., I45 F. Supp. 374 (D.D.C. I956); United States v. Maryland State Licensed Beverage Ass'n, Inc., ${ }_{13} 8$ F. Supp. 685 (D. Md. 1956), reversed on other grounds, 240 F.2d 420 (4th Cir. I957); United States v. P. F. Collier \& Son Corp., 208 F.2d 936 (7th Cir. 1953); United States, v. Auerbach, 68 F. Supp. 776 (S.D. Cal. 1946), in which the word "proceeding" was held to include criminal prosecution.

${ }^{10}$ There appear to be two main reasons for the strict construction of the state "saving" statutes when dealing with abatement of criminal prosecutions: the rule that criminal statutes are to be construed strictly against the state and for the accused, MiLLER, Criminal LaW 37 (1934), and the idea that a corporation cannot sue or be sued unless a statute authorizes it, thus requiring affirmative authority for any such suit. See 16 Fletcher, op. cit. supra note $2, \$ 81_{42}$. But see Bahen \& Wright, Inc. v. Commissioner, 176 F.2d 538 (4th Cir. 1949), in which it was declared that such statutes should be liberally construed.

11 "To hold that criminal actions against corporations abate upon their dissolution invites violation of the law. ..." Marcus, supra note 2, at 703. In United States v. Western Pennsylvania Sand and Gravel Ass'n, I 14 F. Supp. 158 (W.D. Pa. 1953), the court enjoined dissolution of the defendant corporation in order to retain jurisdiction over it. The court felt that to allow such a proceeding to abate would be to provide a method for defrauding the public while avoiding prosecution.

It should be noted, however, that in none of the cases in which dissolution was held to abate the prosecution was it suggested that the corporation dissolved for the purpose of avoiding prosecution. Safervay comes close, for one of the corporations dissolved only 4 days before indictment, the business of the dissolved corporations continued, the physical plant and persounel were left unaffected by dissolution, and even the name persisted. Marcus, supra note 2, at 704. In United States v. Line Material Co., 202 F.2d 929 (6th Cir. 1953), it was conceded that the dissolution was in good faith. The dissolution in United States v. Leche, 44 F. Supp. 765 (E.D. La. 1942), was also in good faith, based on the lack of need for that corporation in the corporate structure. United States v. Union Carbide and Carbon Corp., r32 F. Supp. 388 (D. Colo. 1955), is interesting in that 3 corporations under indictment merging with their parent corporation and the prosecution was held to have abated upon the merger; thus the whole was iminune from indictment even though consisting of guilty (or at least indictable) parts. Abatement as to one of the inerging corporations was reversed, however, by the Vanadium decision. 
ference with federal law and could seriously frustrate federal policies. ${ }^{12}$

Dependence on state winding-up statutes also detracts from the efficacy of the federal laws, since these enactments not only feature dissimilar terms in different states, but also admit of variant intepretations. ${ }^{13}$ For example: The words "actions, suit, and proceeding" in the Delaware statute have been held by some circuits not to countenance criminal prosecutions after dissolution. ${ }^{14}$ In other circuits the same act has been held to sanction criminal actions. ${ }^{15}$ Thus, a corporation's accountability for federal crimes may vary not only in different states, but in different federal courts. Surely a federal criminal statute can and should be more uniformly enforced.

The abatement of antitrust criminal actions seems even more illogical when it is observed that suits for treble damages do survive dissolution..$^{16}$

Finally, even the basic common law analogy between corporate

${ }^{19}$ Comment, 21 U. CHr. L. REv. 480,487 n. 53 (1954), which declares that "in the field of bankruptcy, the federal courts have quite uniformly prevented dissolution from affecting the paramount jurisdiction of the Federal Courts. ..." In United States v. Leche, supra note II, the court labored to avoid subjecting federal law to the state dissolution statutes, though holding that the action abated under common law. This case was strongly criticized in Marcus, supra note 2.

${ }^{13}$ For a recent compilation, see 56 MicH. L. REv. 296, 297 n. 7 (1957).

14 United States v. United States Vanadium Corp., 230 F.2d 646 (1oth Cir.), cert. denied, 351 U.S. 939 ( 1956 ), affirming in part United States v. Union Carbide and Carbon Corp., 132 F. Supp. 388 (D. Colo. 1955); United States v. Line Material Co., 202 F.2d 929 (6th Cir. 1953).

${ }^{15}$ United States v. Maryland State Licensed Beverage Ass'n, Inc., 138 F. Supp. 685 (D. Md. 1956), reversed on other grounds, 240 F. 2 d 420 (4th Cir. 1957); United States v. P. F. Collier \& Son Corp., 208 F.2d 936 (7th Cir. 1953).

Such a diversity in construction may also be illustrated by the conflict as to the meaning of the words "judicial proceeding" in the Texas statute. See note 9 supra.

${ }^{10}$ See Barnes Coal Corp. v. Retail Coal Merchants Ass'n, I28 F.2d 645 (4th Cir. r942) (in which the treble damages action was held not to be abated by a state statute of limitations); Moore v. Backus, 78 F.2d 571 (7th Cir.), cert. denied, 296 U.S. 640 (1935) (in which the treble damages action was held to survive the death of the person injured); United Copper Securities Co. v. Amalgamated Copper Co., 232 Fed. 574 (2nd Cir. 1916) (in which treble damages suit was held to survive against the estate of the decedent). Similarly, an action for an injunction under the antitrust laws has been held not to abate upon dissolution of the defendant corporation. United States v. Trans-Missouri Freight Ass'n, 166 U.S. 290 (1897); United States v. Bates Valve Bag Corp., 39 F.2d 162 (D. Del. 1930). See also United States v. Cigarette Merchandisers Ass'n, Inc, 136 F. Supp. 214, 217 (S.D.N.Y. 1955).

38 Stat. 73 I (1914), 15 U.S.C. $\&$ 16 (1946), affords the complainant a prima facie presumption of liability in case of a criminal conviction of the defendant. Abatement of the criminal suit would seem, therefore, contrary to the policy of this federal statute. 67 HARV. L. REV. 902 (I954). 
and natural persons, which buttresses cases such as Safeway, seems questionable, since the prosecution of a dissolved corporation is really not equatable to the prosecution of a dead man. A corporate wrong will very often be an act by which the corporation profits at the expense of the public, and in such cases, vindication of the public interest would have the same effect-a fine reaching ultimately to the stockholders-whether occurring before or after dissolution. ${ }^{17}$ Thus, such postdissolution suits achieve the desirable purpose of deterring directors and stockholders from authorizing antitrust violations or other illegal acts.

United States v. P. F. Collier E' Son Corp. ${ }^{18}$ was the first of many decisions to oppose the Safeway approach to construction of the saving statutes. The court there held that, although the words "action" and "suit" might not contemplate a criminal prosecution, when the word "proceeding" is added, "a combination is presented which is well near inclusive of all forms of litigation."19 The same rationale was adopted in United States v. Maryland State Licensed Beverage Assn, Inc., ${ }^{20}$ where the court posited that "statutes of this type are broadly remedial" and so should be liberally construed. ${ }^{21}$ The Fifth Circuit went even further in Alamo Fence Co. of Houston v. United States, ${ }^{22}$ asserting that a state can no more continue the existence of a corporation while immunizing it against federal criminal prosecution than it could have created a corporation with such immunity.

Recent decisions have also construed the New York saving statutes to permit criminal actions subsequent to dissolution. In United States v. Cigarette Merchandisers $A s s^{2} n{ }^{23}$ the court relied on controlling state law, which defined "action" to include criminal litigation, ${ }^{24}$ and on the broad policy consideration that corporate liability for criminal acts should

\footnotetext{
${ }^{17}$ See Marcus, supra note 2, at $68 \mathrm{x}$.

${ }^{18} 208$ F.2d 936 (7th Cir. 1953).

${ }^{10} \mathrm{Id}$. at 939 .

${ }^{20} 138$ F. Supp. 685 (D. Md. 1956), reversed on other grounds, 240 F.2d 420 (1957).

${ }_{13} 8$ F. Supp. at 709, quoting from Bahen \& Wright, Inc. v. Commissioner, 176 F.2d 538,539 (4th Cir. 1949).

${ }_{240}^{20}$ F.2d 179 (5th Cir. 1957), based much on Justice Cardozo's dissent in Chicago Title and Trust Co. v. Forty-One Thirty-Six Wilcox Bldg. Corp., 302 U.S. 120, 131 (1937).

${ }^{23}{ }_{136}$ F. Supp. 214 (S.D.N.Y. 1955).

"N.Y. GEN. CONSTR. LAW $§$ II (a) defined "action," concluding that "actions are of two kinds: civil and criminal." And the court also cited a case in which the New York Court of Appeals had construed "action" to include criminal prosecution. People v. Elliott, 172 N.Y. 146,64 N.E. 837 (1902).
} 
not be erased by "dialectical definitions." This decision was followed in United States v. United States Vanadium Corp., ${ }^{26}$ in which the Tenth Circuit indicated a reluctance to apply its own Saferway construction, except to the statutes therein involved. ${ }^{27}$ A r958 decision, United States v. Brakes, Inc., ${ }^{28}$ construed the words "liabilities and obligations" in the New York statute ${ }^{2 \theta}$ to include criminal proceedings. While the court arrived at this result through examination of the construction given the same words in other statutory contexts, ${ }^{30}$ the opinion further suggested that a state may not have the power to insulate a corporation from federal criminal jurisdiction. ${ }^{31}$

Despite the apparent trend toward liberal construction of state winding-up statutes, characterized by the Collier case, some courts yet retain the view propounded in Safeway. The Tenth Circuit, for instance, has refused on the ground of stare decisis expressly to overrule its own Safeway decision, ${ }^{32}$ although the court's failure to advance another basis for the Safeway interpretation indicated a dissatisfaction with the case. Furthermore, the states still ostensibly retain the power to

\footnotetext{
${ }^{25}$ United States v. Cigarette Merchandisers Ass'n, Inc., 136 F. Supp. 214, 217 (S.D.N.Y. 1955).

${ }^{23} 230$ F.2d 646 (10th Cir. 1956), reversing as to the New York statute United States v. Union Carbide and Carbon Corp., 132 F. Supp. 388 (D. Colo. I955), cert. denied, 351 U.S. 939 (1956).

${ }^{27}$ The court in the Vanadium case, supra note 26 , while deciding otherwise as to the New York statute, declined to overrule its Safeway decision upon the word "suits" in the West Virginia statute and upon the Delaware statute.

${ }^{28} \times 57$ F. Supp. $9 \times 6$ (S.D.N.Y. 1958).

${ }^{32}$ N.Y. STOCK CORP. LAW $\S$ ros (8). This section provides for continued existence of a dissolved corporation. It should be noted that United States v. Cigarette Merchandisers Ass'n, Inc., I 36 F. Supp. 214 (S.D.N.Y. 1955), involved a different sectionN.Y. STOCx CORP. LAW $\$$ go-dealing with existence of a corporation upon consolidation.

${ }^{80}$ The court cited People v. Bankers' Capital Corp., 137 Misc. 293, 24I N.Y.S. 693 (Superior Ct. Kings Co. 1930), in which N.Y. GEN. CORP. LAw \& $216(\mathrm{x})$ (e) was construed to permit service of process upon the secretary of state for criminal actions, and In re Grand Jury Subpoenas Duces Tecum, 72 F. Supp. Iox3 (S.D.N.Y. 1947), in which N.Y. STock CORP. LAW $\S 90$ was interpreted to include a criminal prosecution under the Sherman Anti-Trust Act.

81 "I entertain serious doubt as to the power of a state to insulate a corporation from federal criminal prosecution." United States v. Brakes, Inc, 157 F. Supp. $9 \times 6,9 \times 9$ (S.D.N.Y. 1958).

"The court in the Vanadium case gave as its reason for not overruling the Safoway. decision that for one court "lightly" to overrule a decision by an carlier court would put the law in a state of flux so that no one could tell what the law would be without considering the membership of the court. 230 F.2d at 649 . No other reason for retention of the Safoway znle was meationed.
} 
immunize dissolving corporations, either by state court decisions construing statutory language to exclude criminal proceedings or by state legislation.

Of the few attempts to reach a solution to the problem posed by the Safervay rule, most have fallen short of the mark. Two states, ${ }^{33}$ however, have undertaken to relieve their statutes of possible ambiguity by expressly providing for criminal actions against a corporation during its winding-up period. The problem remains in a great many other states, of course, and there is no reason to assume that similar statutes will be passed on a large scale. ${ }^{34}$ A district court suggested another possible solution in United States v. Western Pennsylvania Sand and Gravel $A s s^{3} n^{35}$ when it granted an injunction against the dissolution of a corporation in order to retain jurisdiction over it for criminal prosecution. This technique suffers from several pragmatic defects, however. Since the Government would not usually be informed in advance that a specific corporation is contemplating dissolution, this approach would be of but little practical value unless injunctions were granted automatically upon the filing of an indictment. ${ }^{36}$ Yet, such an automatic injunction policy would be liable unduly to hamper dissolutions and reorganizations based on good faith business necessities. Moreover, an automatic injunction law would not reach a corporation which dissolved prior to its indictment. ${ }^{37}$

\footnotetext{
${ }^{38}$ In North Carolina, N.C. GeN. STAT. $\$ 55-110$ (c) (Supp. 1957), provides that "any claim existing or action or proceeding, civil or criminal, pending . . . may be prosecuted as if such merger or consolidation had not taken place, or such surviving or new corporation may be substituted in its place ...," and $\S 55-114$ (d) provides that “. . . no action or proceding, civil or crimitral, to which a corporation is a party shall abate by reason of such dissolution or filing. ..." (Emphasis added.) In Colorado, CoLo. Rev. Stat. ANN. § 31-6-3 (Supp. 1957), provides that "such dissolution shall not take away or impair any remedy given against such corporation, its stockholders, officers, directors, incorporators or trustees, for any liabilities, whether civil or criminal, incurred previous to such dissolution." (Emphasis added.) See 56 Mich. L. REv, $296(1957)$.

${ }^{34}$ Even if all states did include such clarifying terms in their winding-up statutes, a theoretical objection -would still exist. Each state would still possess the poqver to change its statute and thus to immunize the dissolved corporation. But see United. States v. Brakes, Inc., 157 F. Supp. 9:16 (S.D.N.Y. 1958). ..

${ }^{35}{ }_{114}$ F. Supp. 158 (W,D. Pa. 1953). See also In re Electric. Supply Co., 175 Fed. 612 (S.D. Ga. 1909), in which an injunction against dissolution was granted to preserve federal bankruptcy jurisdiction.

${ }^{38}$ Comment, 21 U. CHI. L. Rev. 480 (r954);" 58 W. VA. L. Rev. 187 (1956). $\because$

${ }^{37}$ The Safeway .case, it should be noted, involved a dissolution before the indictment, as did the Collier and, Brakes cases. . : . :
} 
Perhaps the difficulties inherent in this problem could best be met in a definitive ruling by the United States Supreme Court to the effect that the operation of federal laws cannot be impaired by the familiar vagaries of state saving statutes. Such a ruling would seem reasonably to rest upon the supremacy clause of the Constitution. ${ }^{38}$ The Supreme Court, however, denied certiorari in the United States Vanadium case, ${ }^{39}$ although that decision clearly mirrored the conflict by construing a New York statute to include federal criminal prosecution, while at the same time following the Saferway construction as to Delaware and West Virginia winding-up statutes.

In view of the lack of agreement among the federal courts as to the extent of state power over federal criminal jurisdiction, and in view of the Supreme Court's apparent reluctance to resolve this conflict, it appears that the most feasible way to stabilize the law would be to enact federal legislation expressly continuing corporate criminal responsibility for some period after dissolution. ${ }^{40}$ Such legislation would achieve the sensible result of vindicating the superiority of federal laws over state dissolution statutes.

${ }^{88}$ "[T] $[$ he court has steadily held to the doctrine, vital to the United States as well as to the States, that a state enactment, even if passed in the exercise of its acknowledged powers, must yield, in case of conflict, to the supremacy of the Constitution of the United States and the acts of Congress enacted in pursuance of its provisious." Northern Securities Co. v. United States, 193 U.S. 197, 347 (1904). "The purpose of the supremacy clause was to avoid the introduction of disparities, confusions and conflicts which would follow if the Government's general authority were subject to local controls." United States $\downarrow$ Allegheny County, 322 U.S. 174, 183 (1944). See Marcus, supra note 2 , at 697 .

351 U.S. 939 (1956).

${ }^{10}$ Such an enactment would seem justifiable on the basis that it would merely establish the supremacy of such acts as the Sherman Act over state laws which might interfere with their administration. See note 38 supra. That such a statute would be feasible and that it would not ineet with constitutional objection has been suggested; Comment, 21 U. CHr. L. REv. 480, 488 (1954). And such legislation was called for in United States v. Brakes, Inc., 157 F. Supp: 916 , 919 (S.D.N.Y. 1958): "Since I do not wisb to. make:rulings beyond the necessities of this case, I only note my opinion that it is undesirable to "allow punishment for violation of a federal law to depend on the zagaries of language found in state corporation statutes; and I entertain serious doubts as to the power of a state to insulate a corporation from "federal criminal prosecutiou. In the absence of. a songressional enactment or a statement in the Federal-Criminal Rules, however, I must turn to a consideration of the applicable New York law." ... 